\title{
The contribution of L-selectin to airway hyperresponsiveness in chronic allergic airways disease
}

\section{Simon G Royce \\ Melissa Lee \\ Mimi L K Tang}

Department of Allergy and Immunology, Murdoch Children's Research Institute, The Royal Children's Hospital, Parkville, Victoria 3052, Australia
Correspondence: Mimi L K Tang Department of Allergy and Immunology, Royal Children's Hospital, Parkville, Victoria 3052, Australia

Tel +6I 393455733

Fax +6I 393456348

Email mimi.tang@rch.org.au
This article was published in the following Dove Press journal:

Journal of Asthma and Allergy

23 June 2010

Number of times this article has been viewed

Abstract: L-selectin is a cell adhesion molecule, which mediates leukocyte rolling on bronchopulmonary endothelium. Previous studies in a murine model of allergic airways disease have shown that L-selectin plays a role in the regulation of airway hyperresponsiveness in asthma via mechanisms independent of inflammation. Airway remodeling has been shown to modulate airway hyperresponsiveness independently of inflammation.

Purpose: Our aim was to determine if L-selectin influenced airway hyperresponsiveness via modulation of structural changes as a result of airway remodeling.

Method: A chronic ovalbumin-induced allergic airways disease model was applied to L-selectindeficient mice and wild-type control mice. The development of airway inflammation was assessed by examining leukocyte influx into bronchoalveolar lavage fluid. Airway remodeling changes were determined via histology and morphometric analysis of lung tissue sections, and the development of airway hyperresponsiveness was assessed by invasive plethysmography.

Results: Total cell counts, but not individual differential cell counts, were reduced in the ovalbumin-treated L-selectin-deficient mice compared to wildtype ovalbumin-treated mice. L-selectin-deficient mice had significantly reduced epithelial thickness and smooth muscle thickness. Airway hyperresponsiveness was abrogated in ovalbumin treated L-selectin-deficient mice compared to wild-type controls.

Conclusion: L-selectin plays an important role in regulating airway remodeling in an animal model of chronic allergic airways disease. Abrogated airway hyperresponsiveness may be related to reduced remodeling changes in L-selectin-deficient mice. L-selectin represents a potential target for novel asthma treatment for airway remodeling and airway hyperresponsiveness.

Keywords: asthma, L-selectin, airway hyperresponsiveness, airway remodeling

\section{Introduction}

Three of the most important components of asthma are airway inflammation (characterized by eosinophils, Th2 lymphocytes, mast cells in the airways), airway hyperresponsiveness (AHR; increased reactivity to a bronchoconstrictor), and airway remodeling (structural changes contributing to a thickened hypersecretory bronchial wall). These three components are associated with asthma severity, are interrelated, and may drive each other. ${ }^{1}$ A treatment capable of resolving all three has not yet been identified. The prevalence of asthma remains high and a subset of patients remains symptomatic despite maximal treatment with current therapies. ${ }^{2}$

L-selectin (CD62L) is expressed on all leukocytes and is a member of a glycoprotein family of selectin adhesion molecules including E-, P- and L-selectin. ${ }^{3}$ The submit your manuscript $\mid$ www.dovepress.com

Dovepress

9775
Journal of Asthma and Allergy 2010:3 9-17

(C) 2010 Royce et al, publisher and licensee Dove Medical Press Ltd. This is an Open Access article which permits unrestricted noncommercial use, provided the original work is properly cited. 
selectins are required for leucocyte tethering and rolling on vascular endothelium, important early events in the process of extravasation and therefore in the development of airway inflammation. ${ }^{3}$ L-selectin levels in serum have been reported to be increased in asthma. ${ }^{4}$ Selectins bind to oligosaccharides that decorate mucin-like glycoproteins on the surface of endothelial cells. It is has been suggested that blocking this interaction may be useful in developing new asthma therapies. ${ }^{5,6}$

In order to explore the functions of L-selectin, a mouse deficient in the protein was created by Arbones et al. ${ }^{7}$ These mice have significantly impaired migration of monocytes, lymphocytes and neutrophils to the inflamed peritoneum and show high resistance to lipopolysaccharide-induced toxic shock. ${ }^{8}$ In our previous experiments we have examined the role of L-selectin in the allergic inflammatory responses using an animal model of allergic airways disease (AAD). We found that migration of activated lymphocytes into inflamed lung was inhibited by $30 \%$ in the absence of L-selectin. $^{9}$

To investigate the role of L-selectin in airway inflammation and AHR, we previously applied an acute ovalbumin (OVA) model of AAD to L-selectindeficient mice and $\mathrm{C} 57$ black $6(\mathrm{C} 57 \mathrm{Bl} / 6)$ controls. ${ }^{10} \mathrm{We}$ found that inflammation was equivalent in L-selectindeficient and wild-type mice in both OVA and saline treatments, as assessed by total and differential cell counts in bronchoalveolar lavage (BAL) and analysis of hematoxylin and eosin ( $\mathrm{H}$ and $\mathrm{E}$ ) stains of lung tissue. However, L-selectin-deficient mice had significantly reduced $\mathrm{CD} 3+$ and increased $\mathrm{B} 220+$ populations of lymphocytes in the BAL fluid. Despite similar inflammatory responses (including eosinophils, neutrophils, lymphocytes and monocytes) in the L-selectin-deficient mice and controls, L-selectin-deficient mice had abrogated AHR.

Airway remodeling may have considerable undesirable effects on AHR. It may decrease the ability of the airway to respond to bronchodilators. ${ }^{11}$ Thickening of the airway smooth muscle layer, ${ }^{12}$ as well as thickening of the tissue of the luminal and adventitial sides of the airway smooth muscle layer, have been predicted to contribute to airway narrowing. ${ }^{13-16}$

To examine whether L-selectin may modulate remodeling changes and thereby modulate $\mathrm{AHR}$, we applied a chronic model of AAD to mice deficient in L-selectin. In this model, OVA-sensitised mice develop goblet cell hyperplasia, thickening of the reticular basement membrane and submucosa, and increased total lung collagen, ${ }^{17}$ as well as increased AHR, none of which are observed in short term acute models. ${ }^{18}$ The aim of the current study, therefore, was to determine the effect of L-selectin deficiency on airway remodeling changes in a mouse model of chronic AAD in L-selectin-deficient mice.

\section{Material and methods Mice}

Female mice deficient in L-selectin were generated as previously described. ${ }^{7}$ As chronic OVA-induced models of AAD have been shown to work optimally in the Balb/c strain, ${ }^{19}$ mice were backcrossed for at least ten generations onto a Balb/c background. Age matched wildtype female Balb/c mice obtained from the colony of the Murdoch Children's Research Institute were used as controls. Animals were maintained in a specific pathogen free housing facility. All experimental procedures were approved by the Animal Ethics Committee of the Royal Children's Hospital.

\section{Chronic mouse model of allergic airways disease}

An established model of OVA-induced chronic AAD was used according to the sensitisation and challenge protocol first described by Temelkovski and colleagues (1998) and further characterized by our research group. ${ }^{18-20}$ Briefly, 6-8 week old mice were sensitised via intraperitoneal injection on day 0 and day 14 with $10 \mu \mathrm{g}$ of grade $\mathrm{V}$ chicken OVA (Sigma chemical, St. Louis, Missouri, USA) and $1 \mathrm{mg}$ of aluminium potassium sulfate (alum) adjuvant in $500 \mu \mathrm{l}$ saline (Sigma Chemical, St. Louis, Missouri, USA). Mice were then challenged with nebulised $2.5 \%(\mathrm{w} / \mathrm{v})$ OVA in saline solution using an ultrasonic nebulizer (NE-U07; Omron Corporation, Tokyo, Japan) for 30 minutes, 3 days per week for 6 weeks, from day 21 to 63 . The ultrasonic nebulizer delivered an output of $1 \mathrm{~mL} / \mathrm{min}$ and $1 \mu \mathrm{m}$ to $5 \mu \mathrm{m}$ particle size. Control mice received an equal quantity of alum in $500 \mu \mathrm{L}$ of saline via intraperitoneal injection on day 0 and day 14, and were then exposed to nebulised saline solution. On the day following the final nebulization, invasive plethysmography was performed, and following sacrifice, blood and tissue samples obtained. Twenty mice were used in the saline wild-type experimental group, $\mathrm{n}=20$ in the saline L-selectin-deficient group, $\mathrm{n}=19$ in the wild-type OVA group and $n=23$ in the L-selectin-deficient OVA group. 


\section{Quantitation of serum OVA-specific lgE levels}

Serum was obtained by lethal cardiac puncture of anesthetized mice and stored at $-70^{\circ} \mathrm{C}$ for the measurement of OVA specific IgE. OVA specific IgE levels were determined by ELISA as described previously. ${ }^{9}$

\section{Methacholine-induced airway hyperresponsiveness}

AHR was measured by invasive plethysmography using a Buxco mouse plethysmograph (Buxco Electronics, Troy, New York). Briefly, mice were anesthetized by intraperitoneal injection of ketamine $(200 \mu \mathrm{g} / \mathrm{g})$ and xylazine $(10 \mu \mathrm{g} / \mathrm{g})$, tracheostomized, and the jugular vein cannulated. Mice were ventilated with a small animal respirator (Harvard Apparatus, Holliston, MA) delivering $0.01 \mathrm{~mL} / \mathrm{g}$ body weight, at a rate of 120 strokes/min, in a mouse plethysmograph chamber. Increasing methacholine $(\mathrm{MCh})$ doses were delivered intravenously, and airway resistance measured (Biosystem XA; Buxco Electronics) for 2 min after each dose. Results are expressed as the maximal resistance after each dose of MCh minus baseline (phosphate buffered saline - [PBS] alone) resistance.

\section{Bronchoalveolar lavage}

After measurement of airway reactivity, bronchoalveolar lavage (BAL) was carried out, as described previously..$^{10}$ Total viable cell counts were determined using a hemocytometer with trypan blue exclusion. Differential counts of eosinophils, neutrophils, lymphocytes, and monocytes/macrophages were determined on cytospin smears of BAL samples $\left(4 \times 10^{5}\right.$ cells $)$ from individual mice stained with DiffQuick (Life Technologies, Auckland, New Zealand) after counting 300 cells.

\section{Lung histopathology}

The right lung lobes were fixed in $10 \%$ neutral buffered formalin for 18-24 hours and routinely processed. Serial 5- $\mu \mathrm{m}$ sections taken every $100 \mu \mathrm{m}$ were stained with hematoxylin and eosin for assessment of peribronchial inflammation, with Masson trichrome for assessment of epithelial and subepithelial collagen thickness, and Alcian blue-periodic acid Schiff (AB-PAS) for assessment of goblet cells.

\section{Morphometric analysis of structural changes}

Images of lung tissue sections were captured using a Digital camera (Q Imaging, Burnaby, British Columbia, Canada). A minimum of five bronchi measuring 150-350 $\mu \mathrm{m}$ luminal diameter were analyzed per mouse for the parameters described below using Image Pro-Discovery software (Media Cybernetics, Silver Spring, MD), which was calibrated with a reference micrometer slide. The thickness of the bronchial epithelial layer was measured by tracing around the basement membrane and the luminal surface of epithelial cells, and calculating the area between these lines using a digitizer (Aiptek, Irvine, CA). Total collagen thickness was similarly measured by tracing around the outer extent of the total collagen layer in the submucosal region and around the basement membrane, and the area between these lines calculated. Smooth muscle area was calculated by tracing around the inner and outer surfaces of the smooth muscle layer. Total areas were calculated by subtracting the inner area from the outer area. These areas were expressed per length $(\mu \mathrm{m})$ of basement membrane to account for variation in bronchial diameters. Goblet cells were counted in AB-PAS stained sections and expressed as number of cells per $100 \mu \mathrm{m}$ of basement membrane.

\section{Statistical analysis}

The results were analyzed using a one-way analysis of variance (ANOVA); with Newman-Keuls tests for multiple comparisons between groups. Lung functional studies were analyzed with a two-way ANOVA, with Bonferroni posttest. In this paper $P<0.05$ is described as statistically significant. Morphometry was expressed as median with $95 \%$ confidence interval and analyzed using the Mann-Whitney test.

\section{Results}

\section{Serum OVA specific lgE levels}

OVA-specific serum IgE levels of each mouse were evaluated to ensure that adequate sensitisation was achieved (Figure 1A). OVA-specific IgE titers were significantly elevated in all OVA-sensitised and challenged mice compared to controls $(P<0.001)$. There was no significant difference in OVA-specific IgE levels between wildtype and L-selectindeficient mice groups.

\section{Airway inflammation in allergic airway disease}

Inflammatory responses were assessed ex vivo by performing differential cell counts on cells retrieved by bronchoalveolar lavage (BAL). Total BAL cell counts in saline treated L-selectin-deficient and wild-type mice were equivalent (Figure 1B). Total cell counts retrieved from the airways by BAL were significantly increased in wild type mice following exposure to OVA $(P<0.001)$. Total cell counts in the OVA L-selectin mice were lower than in the wild-type 
A

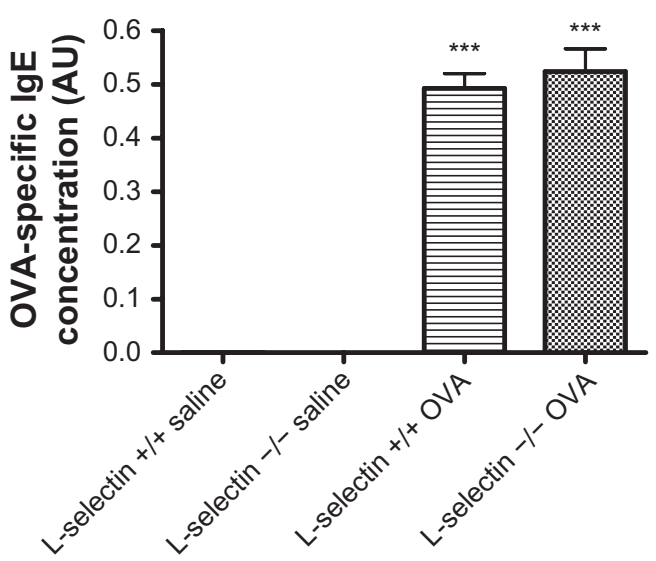

B

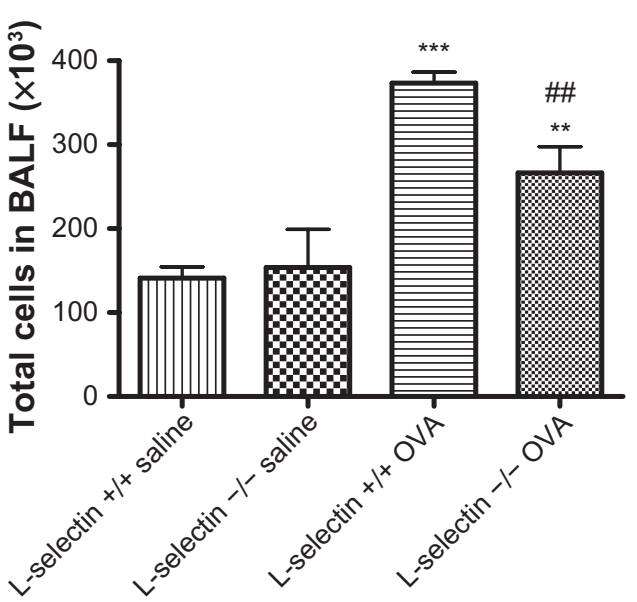

Figure I OVA-specific IgE titers and bronchoalveolar lavage total cell counts. OVA-specific IgE titers were determined in individual serum samples by ELISA and results are expressed as units relative to a standard curve generated from positive control sera (arbitrary units; $\mathbf{A}$ ). The lungs of OVA and saline-treated mice were lavaged with ice-cold PBS. Total cell counts were made by Trypan blue exclusion (B). Results are expressed as total cell number $\times 10^{-3}$ per mL BAL fluid retrieved. ${ }^{\text {** }} P<0.0 \mathrm{I}$, ${ }^{\text {*** }} \mathrm{P}<0.00 \mathrm{I}$ vs respective saline control, ${ }^{\prime} P<0.0$ I vs respective wildtype control.

controls $(P<0.01)$ but still higher than the saline controls $(P<0.01)$.

Differential BAL cell counts revealed significantly increased numbers of eosinophils and lymphocytes in the OVA-treated mice and wild-type OVA mice when compared to saline controls (Table 1). Absence of L-selectin was not associated with any change in numbers of eosinophils, neutrophils, and lymphocytes following OVA exposure when compared to wild-type mice OVA treated mice (Table 1).

\section{Effect of L-selectin loss on airway remodeling changes}

OVA treatment of both wildtype and L-selectin-deficient mice groups resulted in significantly increased epithelial thickness (Figure 2A), collagen deposition in the basement membrane region (Figure $2 \mathrm{~B}$ ), and moderately increased smooth muscle thickness (Figure 2C) as compared to the corresponding saline wild-type and L-selectin-deficient controls. Representative photomicrographs are shown in Figures 3A-D. Goblet cell hyperplasia was also present in both groups of OVA mice, and not the saline treated mice (Figure 2D). L-selectin deficiency did not affect collagen thickness (Figure 2B) or goblet cell hyperplasia (Figure 2D) following OVA treatment compared to OVA treated wild-type mice. However, epithelial thickness (Figure 2A) and smooth muscle thickness (Figure 2C) were significantly decreased in L-selectin-deficient mice in both the saline and OVA treated groups, as compared to saline and OVA treated wild-type mice respectively. Representative photomicrographs are shown in Figures 3A-D.

\section{Effect of L-selectin on airway hyperresponsiveness}

Airway reactivity in saline treated L-selectin-deficient mice was equivalent to that in saline treated wild-type mice. Airway reactivity was significantly higher in OVA treated wildtype mice compared to saline treated wild-type mice $P<0.001$ at the highest three doses of methacholine. Lack of L-selectin significantly abrogated AHR due to OVA sensitization (Figure 4).

Table I Bronchoalveolar fluid differential cell counts

\begin{tabular}{lllll}
\hline & L-selectin +/+ saline & L-selectin -I- saline & L-selectin +/+ OVA & L-selectin -I- OVA \\
\hline Eosinophils & $0.6212 \pm 0.1414$ & $0.1262 \pm 0.08523^{\# \#}$ & $3.985 \pm 0.4050^{* * * *}$ & $5.094 \pm 1.943^{* * * \#}$ \\
Neutrophils & $1.180 \pm 0.1794$ & $9.094 \pm 3.543$ & $5.593 \pm 0.7506^{* * * *}$ & $4.126 \pm 1.217^{\# \#}$ \\
Monocytes & $116.3 \pm 11.74$ & $140.4 \pm 44.09$ & $296.1 \pm 10.51^{* * * *}$ & $206.5 \pm 33.18^{\# \#}$ \\
Lymphocytes & $13.50 \pm 1.387$ & $3.936 \pm 2.072^{\# \#}$ & $69.75 \pm 6.425^{* * * *}$ & $46.83 \pm 9.594^{* * * *}$ \\
\hline
\end{tabular}

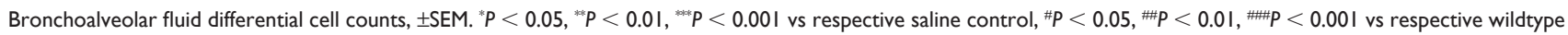
control. 
A

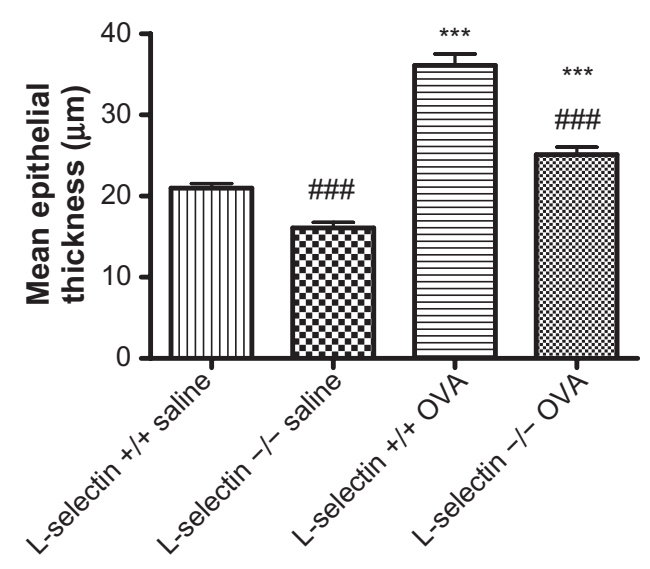

C

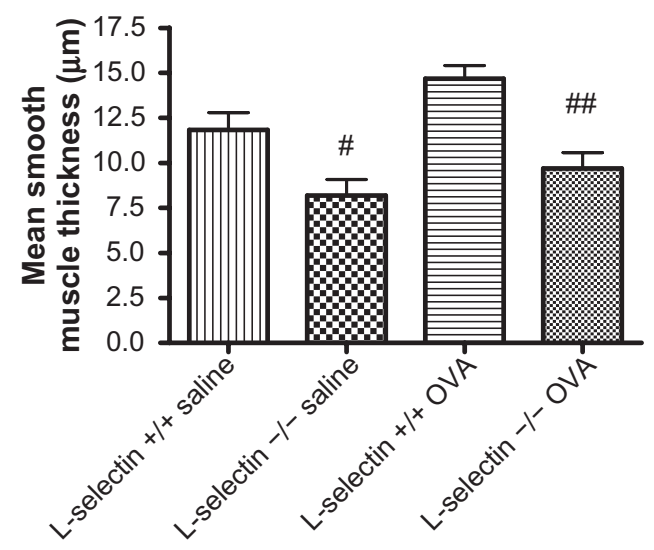

B

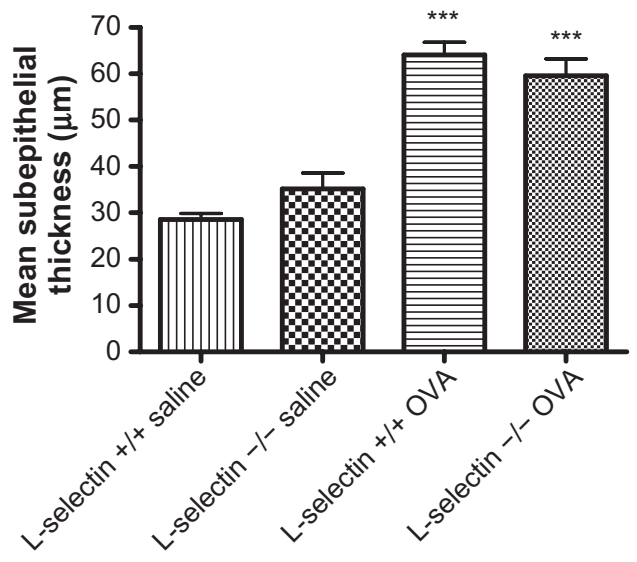

D

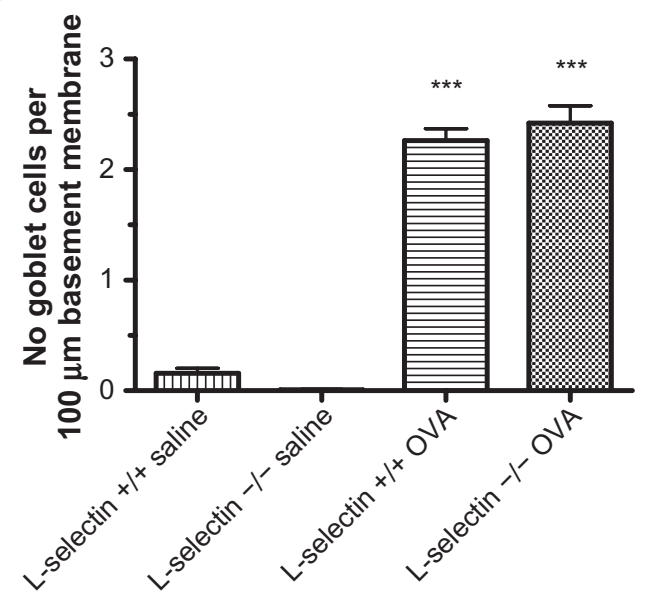

Figure 2 Morphometric analysis of airway wall remodeling changes. Serial sections of paraffin-embedded lung tissues stained with H\&E, Masson's trichrome, and AB-PAS were analyzed using Image Pro-Discovery software (Media Cybernetics, San Diego, California) for thickness of the epithelial (A), subepithelial collagen (B), smooth muscle layer $(\mathbf{C})$, and number of goblet cells $(\mathbf{D}) .{ }^{*} P<0.00$ I vs respective saline control, ${ }^{\#} P<0.05,{ }^{\prime \prime} P<0.0$ I, ${ }^{\#} P<0.00$ I vs respective wildtype control.

\section{Discussion}

Selectin inhibition has been identified as a useful target for therapeutic intervention in asthma. A number of studies have been performed using L-selectin antagonists and antibodies against L-selectin, showing reduction in AHR..$^{21,22}$ Likewise, animals deficient in L-selectin have reduced AHR. ${ }^{9}$ We have previously shown that mice deficient in L-selectin have significantly reduced AHR but without detectable changes in airway inflammation.

There is evidence that airway remodeling makes an important contribution to AHR. ${ }^{23-26}$ As airway remodeling can modulate AHR independent of airway inflammation, we have investigated the role of L-selectin in the regulation of both structural remodeling and AHR in a chronic model of AAD.

In chronic OVA-induced models of AAD, inflammatory cell infiltration is not the predominant pathological feature, and total numbers of inflammatory cells in BAL fluid and in lung tissue are much less than in acute and subacute AAD models. ${ }^{18}$ In the chronic AAD model, only a small proportion of leukocytes in the bronchoalveolar lavage fluid (BALF) are eosinophils, in contrast to shorter term models. In this study eosinophils and neutrophils comprised only small proportions of leukocyte numbers. Furthermore in L-selectin-deficient mice sensitised and challenged with OVA, there was no reduction in these individual leukocyte cell types in the BAL fluid when compared to wildtype controls. Although total BAL fluid cell numbers were decreased compared to OVA wildtype mice, total cell numbers were significantly greater than in the saline groups. As such, and given previous findings, ${ }^{10}$ it appears unlikely that the effect of L-selectin on inflammatory cell inflammation accounts directly for its effect on AHR. 


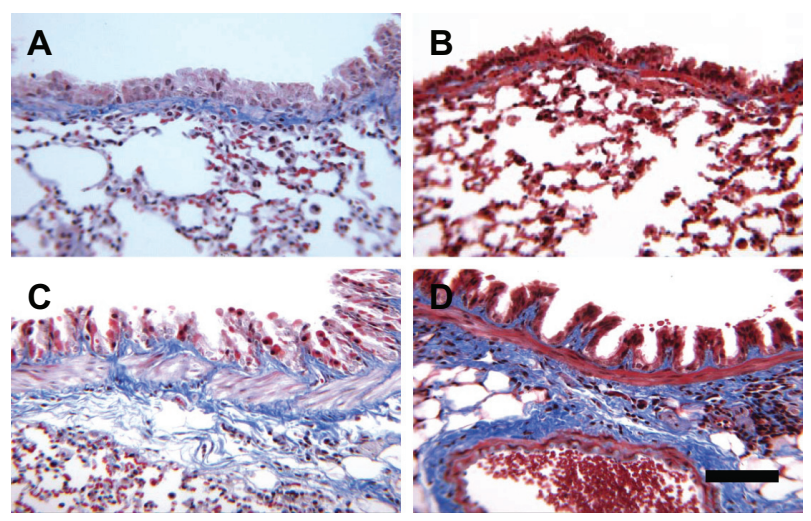

Figure 3 Representative photomicrographs of mouse lung stained with Masson's trichrome. L-selectin +/+ saline (A), L-selectin -/- saline (B), L-selectin +/+ OVA, L-selectin -I- OVA. Bar $=100 \mu \mathrm{m}$.

In the current study we found that L-selectin deficiency dramatically reduced AHR in the chronic mouse model of asthma. Absence of L-selectin was not associated with significant reduction in influx of inflammatory cell types following OVA treatment, although total cell number was slightly reduced in the OVA treated L-selectin-deficient animals as compared to OVA treated wild-type controls. Absence of L-selectin resulted in reduced epithelial thickness and reduced smooth muscle thickness in OVA treated L-selectin-deficient mice as compared to OVA treated wild-type mice. Both of these structural changes have been well characterized in airway remodeling, and are thought to contribute to AHR in asthma. Absence of L-selectin had no effect on goblet cells or collagen deposition.

Thickening of the airway wall is likely to contribute to AHR as it reduces the amount of muscle contraction required to close the airway. ${ }^{12,14,27}$ Airway epithelial thickness has been shown to be significantly elevated in patients with severe asthma ${ }^{28}$ and in cases of fatal asthma. ${ }^{14,29}$ Epithelial remodeling can be promoted by a variety of causes including viral infection ${ }^{30}$ or eosinophilic inflammation. ${ }^{31}$ Rosen and colleagues found that a major ligand of L-selectin recognized by MECA-79 was localized to bronchial epithelial cells and submucosal glands in sheep. ${ }^{22}$ It is probable that these ligands are mucins of a type also found in the human airway epithelium. ${ }^{32,33}$ Reduced epithelial thickness in L-selectindeficient mice may be related to the absence of L-selectin binding to epithelial cells.

Smooth muscle thickness is also an important feature of airway remodeling in asthma. ${ }^{34}$ Thickening of the smooth muscle bundle is due to myocyte hypertrophy and hyperplasia, although there is more evidence for the latter. Smooth muscle cell hyperplasia may be caused by proliferation of myocytes, reduced apoptosis, or migration of mesenchymal cells or circulating progenitor cells that differentiate into myocytes via the fibrocyte/fibroblast

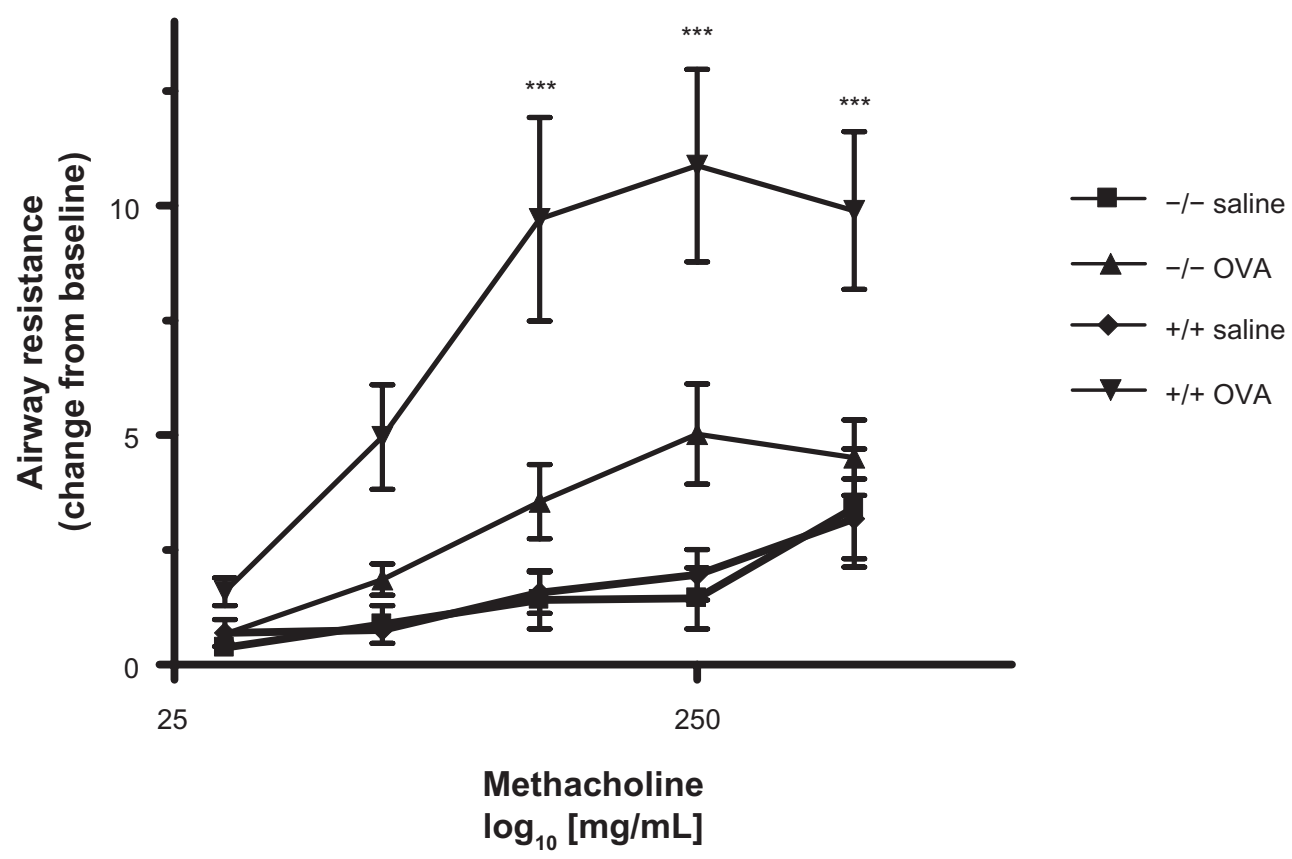

Figure 4 Airway hyperresponsiveness. Methacholine-induced AHR was measured by plethysmography $24 \mathrm{~h}$ after the final aerosol challenge. Results are presented as $+/-$ standard deviation and expressed as the resistance change from baseline (PBS only) responses of individual mice. Two-way ANOVA with Bonferroni post-test was used to compare groups. ${ }^{* * *} P<0.01,{ }^{* * * *} P<0.001$ vs respective saline control, ${ }^{\# \# P} P<0.00$ I vs respective wildtype control. 
lineage. Loss of L-selectin may inhibit recruitment of stem cells that are recruited during remodeling, leading to increased epithelial and smooth muscle thickness. Little is known of the mechanisms regulating ontogeny of various cell layers in the airway wall, but it seems that loss of L-selectin from the surface of circulating cells may provide possible explanation for altered lung development in L-selectindeficient animals. It has been suggested that pan selectin antagonists may influence resident lung cell interactions, and have been shown to be efficacious in reducing early and late phase asthma response and AHR when administered in an inhaled form as well as intravenously. ${ }^{35}$ Further investigation is required into the effect of L-selectin on development at other organ sites and its influence on remodeling in other foregut-derived tissues. New functions for L-selectin are still being investigated, with the recent discovery that L-selectin is expressed on cytotrophoblasts, and interacts with ligands on the uterine epithelial surface. ${ }^{36}$

In the setting of airway remodeling in asthma, L-selectin may play a role in regulating numbers of circulating collagen $1^{+} \mathrm{CD}_{4} 5^{+}$and $\mathrm{CD} 34^{+}$fibrocytes in the lung. Fibrocytes are unique blood-borne cells with fibroblast-like properties. ${ }^{37}$ These cells increase in the lung after allergen challenge and differentiate into collagen-producing myofibroblasts. ${ }^{38,39}$ They have a number of functions other than promoting fibrosis. They are potent antigen presenting cells, and can elicit the recruitment and activation of $\mathrm{T}$ cells, as well as secrete the chemokines, cytokines, and growth factors that mediate fibroproliferation. There is a close relationship between the numbers of fibrocytes in the airway, with basement membrane thickness. Furthermore it has been hypothesized the circulating fibrocytes may also be important in contributing to other aspects of airway remodeling. Circulating fibrocytes have been shown to different into airway myofibroblasts and smooth muscle cells in animal models ${ }^{39,40}$ in addition, blocking fibrocyte chemokine ligand CXCL12 has been shown to reduce fibrocyte accumulation and fibrosis in a bleomycin murine model. ${ }^{40,41}$

Our study indicates that L-selectin deficiency results in altered bronchial structure even in the saline group (ie, independently of OVA induced sensitisation and inflammation). This change is however undetectable by AHR in saline treatment mice, but may be detectable by other measures of baseline lung function.

Interestingly in the OVA L-selectin-deficient group, a modest reduction in total inflammation and no significant reduction in any individual cell type has resulted in significantly reduced AHR compared to OVA treated wild-type mice, and only slightly higher than the saline groups. Recent phase IIa trials with the pan-selectin antagonist bimosiamose resulted in reduced airway recruitment of eosinophils in asthma patients. ${ }^{35}$ In our previous studies, L-selectin-deficient mice had markedly reduced airway hyperresponsiveness without detectable change in airway inflammation; however airway remodeling changes in epithelium and airway smooth muscle changes have been observed in our current chronic allergic airways disease model study.

The effects of L-selectin antagonists on airway remodeling changes in humans have not been reported, although the number of studies is limited. Further investigation is required to determine whether the findings in this mouse model are also evident in human asthma. As L-selectin inhibition is reported to reduce airway inflammation in humans, it is likely to have some impact on airway remodeling. Eosinophils promote various aspects of remodeling largely via cytokine production (TGF $\beta$, IL4, IL13, VEGF, FGF2). ${ }^{42}$ Neutrophils also contribute to remodeling through the effects of neutrophil elastases, which cause mucous cell hypertrophy and hyperplasia, ${ }^{43}$ and stimulate expression of mucin genes. ${ }^{44}$ Cytokines produced by Th2 lymphocytes have multiple pro-remodeling effects, ${ }^{45}$ while mast cell tryptases stimulate myocyte proliferation. ${ }^{46}$ Airway inflammation may also result in airway remodeling by alternative pathways such as response to epithelial damage ${ }^{47}$ as structural changes are present in the airways of children before asthma symptoms. ${ }^{48}$

\section{Conclusion}

In summary, the relative contributions of airway inflammation and airway remodeling to airway hyperresponsiveness remains complex and controversial. New treatments for severe asthma must preferably have combined effects on airway inflammation and airway remodeling, as well as airway hyperresponsiveness. Our findings further support L-selectin as a potential target for asthma therapeutics, with dramatic effects on airway hyperresponsiveness and remodeling.

\section{Acknowledgments/disclosure}

This study was funded through a Murdoch Children's Research Institute Project Grant and a National Health and Medical Research Council Project Grant. The authors would like to thank DrT F Tedder, Duke University Medical Centre for providing the L-selectin deficient mice. 


\section{References}

1. Tang ML, Wilson JW, Stewart AG, Royce SG. Airway remodelling in asthma: current understanding and implications for future therapies. Pharmacol Ther. 2006 Nov;112(2):474-488.

2. Adcock IM, Lane SJ. Corticosteroid-insensitive asthma: molecular mechanisms. J Endocrinol. 2003 Sep;178(3):347-355.

3. Rosen SD. Homing in on L-selectin. J Immunol. 2006 Jul 1;177(1):3-4.

4. Oymar K, Bjerknes R. Differential patterns of circulating adhesion molecules in children with bronchial asthma and acute bronchiolitis. Pediatr Allergy Immunol. 1998 May;9(2):73-79.

5. Kneuer C, Ehrhardt C, Radomski MW, Bakowsky U. Selectins-potential pharmacological targets? Drug Discov Today. 2006 Nov;11(21-22): 1034-1040.

6. Woodside DG, Vanderslice P. Cell adhesion antagonists: therapeutic potential in asthma and chronic obstructive pulmonary disease. BioDrugs. 2008;22(2):85-100.

7. Arbones ML, Ord DC, Ley K, et al. Lymphocyte homing and leukocyte rolling and migration are impaired in L-selectin-deficient mice. Immunity. $1994 \mathrm{Jul} ; 1(4): 247-260$.

8. Tedder TF, Steeber DA, Pizcueta P. L-selectin-deficient mice have impaired leukocyte recruitment into inflammatory sites. J Exp Med. 1995 Jun 1;181(6):2259-2264.

9. Keramidaris E, Merson TD, Steeber DA, Tedder TF, Tang ML. L-selectin and intercellular adhesion molecule 1 mediate lymphocyte migration to the inflamed airway/lung during an allergic inflammatory response in an animal model of asthma. JAllergy Clin Immunol. 2001 Apr;107(4):734-738.

10. Fiscus LC, Van Herpen J, Steeber DA, Tedder TF, Tang ML. L-Selectin is required for the development of airway hyperresponsiveness but not airway inflammation in a murine model of asthma. J Allergy Clin Immunol. 2001 Jun;107(6):1019-1024.

11. Wilson JW, Li X, Pain MC. The lack of distensibility of asthmatic airways. Am Rev Respir Dis. 1993 Sep;148(3):806-809.

12. Wiggs BR, Bosken C, Pare PD, James A, Hogg JC. A model of airway narrowing in asthma and in chronic obstructive pulmonary disease. Am Rev Respir Dis. 1992 Jun;145(6):1249-1250.

13. Moreno RH, Hogg JC, Pare PD. Mechanics of airway narrowing. Am Rev Respir Dis. 1986;133(6):1171-1180.

14. James A, Pare P, Hogg J. The mechanics of airway narrowing in asthma. Am Rev Respir Dis. 1989;139(1):242-246.

15. Macklem P. Theoretical basis of airway instability. Roger S Mitchell Lecture. Chest. 1995;107 3 Suppl:87S-88S.

16. McParland BE, Macklem PT, Pare PD. Airway wall remodeling: friend or foe? J Appl Physiol. 2003;95:426-435.

17. Kumar RK, Foster PS. Murine model of chronic human asthma. Immunol Cell Biol. 2001 Apr;79(2):141-144.

18. Locke NR, Royce SG, Wainewright JS, Samuel CS, Tang ML. Comparison of airway remodeling in acute, subacute, and chronic models of allergic airways disease. Am J Respir Cell Mol Biol. 2007 May;36(5):625-632.

19. Temelkovski J, Hogan SP, Shepherd DP, Foster PS, Kumar RK. An improved murine model of asthma: selective airway inflammation, epithelial lesions and increased methacholine responsiveness following chronic exposure to aerosolised allergen. Thorax. 1998 Oct;53(10):849-856.

20. Mookerjee I, Solly NR, Royce SG, Tregear GW, Samuel CS, Tang ML. Endogenous relaxin regulates collagen deposition in an animal model of allergic airway disease. Endocrinology. 2006 Feb;147(2):754-761.

21. Abraham WM, Ahmed A, Sabater JR, et al. Selectin blockade prevents antigen-induced late bronchial responses and airway hyperresponsiveness in allergic sheep. Am J Respir Crit Care Med. 1999 Apr;159(4 Pt 1):1205-1214.

22. Rosen SD, Tsay D, Singer MS, Hemmerich S, Abraham WM. Therapeutic targeting of endothelial ligands for L-selectin (PNAd) in a sheep model of asthma. Am J Pathol. 2005 Mar;166(3):935-944.
23. Laprise C, Laviolette M, Boutet M, Boulet LP. Asymptomatic airway hyperresponsiveness: relationships with airway inflammation and remodelling. Eur Respir J. 1999 Jul;14(1):63-73.

24. Jeffery PK, Wardlaw AJ, Nelson FC, Collins JV, Kay AB. Bronchial biopsies in asthma. An ultrastructural, quantitative study and correlation with hyperreactivity. Am Rev Respir Dis. 1989 Dec;140(6): 1745-1753.

25. Boulet LP, Chakir J, Dube J, Laprise C, Boutet M, Laviolette M. Airway inflammation and structural changes in airway hyper-responsiveness and asthma: an overview. Can Respir J. 1998 Jan-Feb;5(1):16-21.

26. Boulet LP, Laviolette M, Turcotte H, et al. Bronchial subepithelial fibrosis correlates with airway responsiveness to methacholine. Chest. 1997 Jul;112(1):45-52.

27. Wiggs BR, Moreno R, Hogg JC, Hilliam C, Pare PD. A model of the mechanics of airway narrowing. J Appl Physiol. 1990 Sep 1; 69(3):849-860.

28. Cohen L, E X, Tarsi J, et al. Epithelial cell proliferation contributes to airway remodeling in severe asthma. Am J Respir Crit Care Med. 2007 Jul 15;176(2):138-145.

29. Kuwano K, Bosken CH, Pare PD, Bai TR, Wiggs BR, Hogg JC. Small airways dimensions in asthma and in chronic obstructive pulmonary disease. Am Rev Respir Dis. 1993 Nov;148(5):1220-1225.

30. Walter MJ, Morton JD, Kajiwara N, Agapov E, Holtzman MJ. Viral induction of a chronic asthma phenotype and genetic segregation from the acute response. J Clin Invest. $2002 \mathrm{Jul} ; 110(2)$ : $165-175$.

31. Ricciardolo FL, Di Stefano A, van Krieken JH, et al. Proliferation and inflammation in bronchial epithelium after allergen in atopic asthmatics. Clinical and Experimental Allergy. 2003 Jul;33(7):905-911.

32. Crottet P, Kim YJ, Varki A. Subsets of sialylated, sulfated mucins of diverse origins are recognized by L-selectin. Lack of evidence for unique oligosaccharide sequences mediating binding. Glycobiology. 1996 Mar;6(2):191-208.

33. Mannori G, Crottet P, Cecconi O, et al. Differential colon cancer cell adhesion to E-, P-, and L-selectin: role of mucin-type glycoproteins. Cancer Res. 1995 Oct 1;55(19):4425-4431.

34. Benayoun L, Pretolani M. Airway remodeling in asthma: mechanisms and therapeutic perspectives. MS Md Sci. 2003 Mar;19(3): 319-326.

35. Romano SJ. Selectin antagonists: therapeutic potential in asthma and COPD. Treat Respir Med. 2005;4(2):85-94.

36. Genbacev OD, Prakobphol A, Foulk RA, et al. Trophoblast L-selectinmediated adhesion at the maternal-fetal interface. Science. 2003 Jan 17; 299(5605):405-408.

37. Lama VN, Phan SH. The extrapulmonary origin of fibroblasts: stem/progenitor cells and beyond. Proc Am Thorac Soc. 2006 Jun;3(4):373-376.

38. Nihlberg K, Larsen K, Hultgardh-Nilsson A, Malmstrom A, Bjermer L, Westergren-Thorsson G. Tissue fibrocytes in patients with mild asthma: a possible link to thickness of reticular basement membrane? Respir Res. 2006;7:50.

39. Schmidt M, Sun G, Stacey MA, Mori L, Mattoli S. Identification of circulating fibrocytes as precursors of bronchial myofibroblasts in asthma. J Immunol. 2003;171(1):380-389.

40. Murphy J, Summer R, Fine A. Stem cells in airway smooth muscle: state of the art. Proc Am Thorac Soc. 2008 Jan 1;5(1):11-14.

41. Phillips RJ, Burdick MD, Hong K, et al. Circulating fibrocytes traffic to the lungs in response to CXCL12 and mediate fibrosis. J Clin Invest. 2004 Aug;114(3):438-446.

42. Kay AB, Phipps S, Robinson DS. A role for eosinophils in airway remodelling in asthma. Trends Immunol. 2004;25(9):477-482.

43. Stockley RA, Grant RA, Llewellyn-Jones CG, Hill SL, Burnett D. Neutrophil formyl-peptide receptors. Relationship to peptide-induced responses and emphysema. Am J Respir Crit Care Med. 1994 Feb;149 (2 Pt 1):464- 468 . 
44. Fischer BM, Voynow JA. Neutrophil elastase induces MUC5AC gene expression in airway epithelium via a pathway involving reactive oxygen species. Am J Respir Cell Mol Biol. 2002 Apr;26(4):447-452.

45. Wills-Karp M, Chiaramonte M. Interleukin-13 in asthma. Curr Opin Pulm Med. 2003;9(1):21-27.

46. Akers IA, Parsons M, Hill MR, et al. Mast cell tryptase stimulates human lung fibroblast proliferation via protease-activated receptor-2. Am J Physiol Lung Cell Mol Physiol. 2000 Jan 1;278(1): L193-L201.
47. Phipps S, Benyahia F, Ou TT, Barkans J, Robinson DS, Kay AB. Acute allergen-induced airway remodeling in atopic asthma. American Journal of Respiratory Cell and Molecular Biology. 2004;31(6):626-632.

48. Phunek P, Roche W, Turzikora Jea. Eosinophilic inflammation in the bronchial mucosa of children with bronchial asthma. Eur Respir J. 1997; $10: 160$ s.

\section{Publish your work in this journal}

The Journal of Asthma and Allergy is an international, peer-reviewed open-access journal publishing original research, reports, editorials and commentaries on the following topics: Asthma; Pulmonary physiology; Asthma related clinical health; Clinical immunology and the immunological basis of disease; Pharmacological interventions and

\section{Dovepress}

new therapies. Issues of patient safety and quality of care will also be considered. The manuscript management system is completely online and includes a very quick and fair peer-review system, which is all easy to use. Visit http://www.dovepress.com/testimonials.php to read real quotes from published authors.

Submit your manuscript here: http://www.dovepress.com/journal-of-asthma-and-allergy-journal 